\title{
Sports Education Institutions in Turkey and Their Managerial Effectiveness
}

\author{
Fatih Mehmet Uğurlu1,* \\ ${ }^{1}$ School of Physical Education and Sports, Frrat University, Elazığ 23000, Turkey \\ *Correspondence: School of Physical Education and Sports, Firat University, Elazı̆ 23000, Turkey. Tel: \\ 90-535-620-7177. E-mail: ugurlu76tr@hotmail.com
}

Received: August 15, 2018

Accepted: September 30, $2018 \quad$ Online Published: October 17, 2018

doi:10.5430/wje.v8n5p172

URL: https://doi.org/10.5430/wje.v8n5p172

\begin{abstract}
The aim of this study is to investigate the managerial effectiveness of administrators according to the opinions of the academicians who work in sports sciences faculties in Turkey. In order to collect the opinions of the academicians, the "Managerial Effectiveness Evaluation (MEE) Scale" was adopted. The MEE scale consists of 5 subscales and 44 matters. The gathered data was analyzed with parametric and non-parametric tests by using SPSS 22.0 package software. Additionally, in order to determine the level and course of the relationship between the dependent variables, "Pearson correlation analysis" was conducted. To better explain the quality of the determined relationship and determine the prediction between MEE scale and its subscales, "multiple regression" analysis was conducted. Considering the opinions of the academicians, significant differences were determined in the gender variable in the "Leadership" subscale $(\mathrm{p}<0.05)$. In the correlation analysis, it was determined that the strongest relationship was between the MEE scale and the "Planning and Decision-making" subscale $(\mathrm{r}=0.980 ; \mathrm{p}<0.001)$ in a positive way and at very high level. With the regression analysis, four distinct model structures were built with 6 independent variables (MEE scale and its subscales). As a result of these 4 model structures, it was determined that the subscale with the strongest prediction of the MEE scale was the "Planning and Decision-making" subscale. Furthermore, it was determined that this subscale predicted the $96 \%$ of the variance of MEE scale $\left(\mathrm{R}^{2}=0.960\right)$.
\end{abstract}

Keywords: managerial effectiveness, sports education, higher education, academicians, Turkey

\section{Introduction}

Although there are shared points in the definition of the concept of management, various authors and researchers evaluated the concept from different points of view. Management covers an entirety of actions performed to the achieve certain goals of a formal organization, direct the manpower and material resources toward these aims, their supervision and evaluation. The main aim of management, regardless of the type of organization, is to coordinate the material resources and individuals' efforts in order to achieve the aims of the organization. The essence of management is to effectively use manpower and material resources in order to achieve a common goal (Cook, 2008; Aydin, 1994).

Today, managers work in complicated working environments where globalization, rapid technological developments, diminished resources and growing costs exist. Managers are responsible for solving problems, investigating reasons, using resources in the most rational and scientific way, providing motivation for workers and achieving determined goals. Additionally, the responsibilities of managers are significant in terms of not only for solving problems according to the aims of the organization when they arise but also for keeping the organization away from the problems that are not in line with the aims of the organization (Doğan \& Şahin, 2011). Compared to past, it is now more necessary for managers to use the creativity and entrepreneurship of human resource in the organization, enabling opportunity for individuals to develop and motivate them to work above the minimum (Dilber, 1976).

From past to present, various definitions of effectiveness were conceived. Macbeath (1998) defined effectiveness as the success provided in outputs; Hoy \& Miskel (1996) defined it as the level of achieving the aim and the ability to adapt to the environment; Cyril (1999) defined the concept as the ability to obtain the required resources. Generally, effectiveness demonstrates the ratio of the input and output (Farahbakhsh, 2007). Effectiveness is a dimension of 
performance that determines the level of achieving an aim as a result of the activities performed by an organization. In order for an aim to be achieved at the desired level in an organization, it is necessary for the humans, the organization, to be efficient and qualified (Horngren, Foster, \& Datar, 2000; Başaran, 1982).

A number of definitions for the managerial effectiveness, which has a significant value for the subject of management, were conceived. Generally, managerial effectiveness ensures the optimal use of human and material resources of the organization in order to achieve the determined goals, adapt to the environment, provide integration, create and sustain organizational values. Managerial effectiveness is of vital importance in managers' self-improvement and the organizations' development, ultimately in the actualization and maintenance of the modern society. Managerial effectiveness is a type of effectiveness that is a product of a multifaceted and concentric series of relationship and the manager's behavior. Organizations provide managerial effectiveness through managerial functions such as planning, supervising, decision-making, communication and affecting (Cook, 2008; Karatepe, 2005; Karsl1, 2004). In the study conducted by Farahbakhsh (2007), it was suggested that a systematic approach to managerial functions is necessary for improving managerial effectiveness. The necessary activities to improve managerial effectiveness were stated as the following:

- The aims should be carefully set and should be comprehensible and measurable. In the case of a change in the environment, the aims should be revised.

- Suitable plans, policies and programs should be prepared and these should be transmitted to all who serve for the achievement of the goal.

- Authorizations and responsibilities should be created suitably.

- A suitable performance evaluation system should be present to measure how effective the actions performed are.

- Performance-based evaluation systems, which contain evaluation criteria intended for improving the performance, should be defined and implemented.

The managerial effectiveness of an organization rests with the managers. It is suggested that the more qualified the managers of an organization, the more qualified the organization. In this sense, a manager is an individual who uses the existing organizational structure and procedure in order to achieve the aims of the organization (Y1lmaz \& Taşdan, 2006). The quality of managers is related to the performance of the management in their basic functions. While determining the effectiveness, managers' influence on subdivisions' achievement of their aim and individual qualities are observed (Murry, 1993).

Universities exist in an environment where there are continuous changes and information rapidly grows and evolves, and they experience a number of problems. In such an environment, it is of great significance for the managers serving in universities to demonstrate managerial effectiveness. Global competitiveness, which effects universities and is one of the most vital factors, has become an element of pressure for universities in competing with other universities not only on a national level but also on an international level and in improving their organizational performance. This pressure forces universities to revise their aims, structures, processes and outputs and brings novel initiatives regarding how the universities are managed (Karakaya, 2013; İra, 2011; Popli, 2005). Briefly, measuring the effectiveness in managerial functions provides a significant contribution to the effective management of the organization. Evaluation of the managerial effectiveness in universities by considering the management function would ensure the achievement of predetermined goals and the effective management in these institutions.

The globalization process has brought a number of responsibilities for faculties of sports sciences by raising qualified physical education teachers, sports managers, sports coaches, and recreation managers and improving these qualities. This responsibility is related to the fact that faculties of sports sciences are significant academic departments, which perform actions aimed at contributing to the quality of education in the university, fostering the university culture and improving the quality of university culture. The aim of this study conducted within this framework is to determine the managerial effectiveness levels of managers who serve in Faculties of Sports Sciences according to the opinions of academicians who serve in these faculties. Because the achievement of aims in an organization is under the responsibilities of managers, this study was conducted with the aim of providing better management in Faculties of Sports Sciences. Investigating managerial effectiveness in Faculties of Sports Sciences is of great significance in terms of correctly understanding and analyzing the functions of today's modern organizational structure. These type of studies, in this period of global competition, will provide positive benefits for the change and development in Faculties of Sports Sciences. Establishing an academic and democratic culture by the effective management of Faculties of Sports Sciences will provide significant contributions to the field of sports sciences. This study also 
constitutes a significance thanks to the aims of investigating the need for managerial effectiveness is Faculties of Sports Sciences not only considering the use of organizational resources but also sustaining the respect and prestige that are readily recognized. Additionally, determining or explaining the managerial effectiveness in Faculties of Sports Sciences will provide a contribution to filling the gap in the related literature.

\section{Method}

In this study, the "quantitative method" was adopted and the relational screening model was chosen as the research design. Karasar (2009) defined the relational screening model as a research model that aims to determine the existence of the level of covariance between two or more variables.

In order to collect the data from the study group, the "Managerial Effectiveness Evaluation (MEE) Scale", which was developed by Murry (1993) and revised in 2009, was adopted (İra \& Şahin, 2010). During the development process of the scale in 1993, the "Delphi Method" was adopted. The "Delphi Method" is a technique that is implemented by the way of reconciling individuals or groups, who take different approaches to a problem situation, without having an encounter. The "Delphi Method" is creating a structure in which a group of individuals can establish an effective communication in order to overcome a complicated problem (Şahin, 2001). The following steps were taken during the development process of the "MEE Scale": Murry (1993) determined 70 matters in the management processes' planning, organizing, supervising, human resources management, leadership, communication, teamwork, problem-solving and decision-making processes. These matters were sent to 33 university managers and they were asked to evaluate these matters and comment on them. Then, expert opinions were asked and statistical calculations were conducted, creating the "MEE Scale". MEE scale was also revised by J. Murry in 2009 by using the "Delphi Method" once again. The adaptation of the MEE scale into Turkish was conducted İra \& Şahin (2010). After providing the language validity of MEE scale, the necessary adjustments in line with the expert opinions were performed for achieving the adaptation of the scale for its implementation in Turkish universities. The scale, which was provided with content validity and face validity, was turned into a scale form that covers management functions such as planning, organizing, supervising, human resources management, leadership, communication, teamwork, problem-solving and decision-making. The factor structure of the MEE scale was investigated by exploratory factor analysis. Finally, İra \& Şahin (2010) finalized the scale with 5 subscales and 44 matters. The Cronbach alpha internal consistency coefficients of the subscales of the MEE scale were determined as 0.94 for "Planning and Decision-making (PDM) Subscale", 0.94 for "Organizing and Human Resources Management (OHRM) Subscale", 0.89 for "Teamwork (TW) Subscale", 0.90 for "Communication (COM) Subscale" and 0.84 for "Leadership (LED) Subscale". The internal consistency Cronbach alpha internal consistency coefficient of 0.95 for the whole MEE scale was regarded as proof for the construct validity and reliability of the scale. Additionally, the value range for the MEE scale was formed as, from positive to negative, "Completely Agree", "Agree", "Partially Agree", "Disagree" and "Completely Disagree".

The population of the study consists of academicians who serve in 13 Faculties of Sports Sciences that provides sports education at the higher education level in Turkey. The study group consists of 157 academicians who were chosen by the random method. The universities of the Faculties of Sports Sciences in which the study group serves are as the following: "Fırat University", "İnönü University", "Selçuk University", "Marmara University", "Anadolu University", "Ondokuz Mayls University", "İstanbul University", "Pamukkale University", "Atatürk University", "Gazi University", "Sakarya University", "Çanakkale University" and "Uludağ University". The personal information of the study group is as the following: the study group consists of 123 male academicians and 34 female academicians. In terms of the education level, 128 of the academicians had Ph.D. Degrees while 25 of them had Master's Degrees and 4 of them had Bachelor's degrees. In terms of the period of academic service, 40 of the academicians in the study had service times of 21 years or above while 76 of them had 11-20 and 41 of them had $0-10$ years. In terms of the academic titles, 21 of the academicians in the study had titles of Prof. Dr. while 37 of them had Assoc. Prof., 44 of them had Dr., 33 of them had Instructor and 22 of them had Research Assistant.

The data of the study was collected by e-mail between 01 May 2018 and 01 June 2018. Within the framework of the study, the e-mail addresses of the academicians serving in Faculties of Sports Sciences were obtained by using the universities' websites. The MEE Scale form was prepared in "Google Forms" and sent to 447 academicians via e-mail. Then, three rounds of reminder e-mails with one-week intervals were sent (reminding the academicians to fill out the scale if they have not yet and ignore the e-mail in case they have already filled it out). 161 academicians provided their feedback on 01 June 2018. The data of 4 academicians were excluded in the study due to incomplete MEE Scale form and the opinions of 157 academicians were evaluated.

As a result of the data collected from 157 academicians, the normality test was conducted in order to determine 
whether the MEE scale and its subscales formed a normality assumption. As it is presented in Table 1, it was determined that the kurtosis and skewness values of MEE scale and its subscales were between +1.5 and -1.5 . Thus, it was observed that the normality occurred. This is because Tabachnick \& Fidell (2007) pointed out that the values of skewness and kurtosis between +1.5 and -1.5 could indicate that the distribution is normal. Additionally, Q-Q graphs of MEE scale and its subscales were observed in order to investigate whether a normality assumption existed (Figure 1). It was determined that these findings also satisfied the assumptions of correlation analysis and regression analysis conducted at the end of the study. It was also concluded that the linearity condition, the second presupposition of the regression analysis, was provided.

Table 1. Results of the Normality Test for MEE Scale and Its Subscales (Skewness and Kurtosis Values)

\begin{tabular}{cccccc}
\hline $\begin{array}{c}\text { The Scale and Its } \\
\text { Subscales }\end{array}$ & N & Mean & $\begin{array}{c}\text { Standard } \\
\text { Deviation }\end{array}$ & Skewness & Kurtosis \\
\hline MEE Scale & 157 & 2.88 & 0.81 & {$[0.071 ; 0.194]$} & {$[-0.156 ; 0.385]$} \\
PDM Subscale & 157 & 2.76 & 0.82 & {$[0.159 ; 0.194]$} & {$[-0.357 ; 0.385]$} \\
OHRM Subscale & 157 & 2.82 & 0.88 & {$[0.170 ; 0.194]$} & {$[-0.136 ; 0.385]$} \\
TW Subscale & 157 & 3.09 & 0.80 & {$[-0.270 ; 0.194]$} & {$[0.381 ; 0.385]$} \\
COM Subscale & 157 & 3.01 & 0.91 & {$[0.027 ; 0.194]$} & {$[-0.206 ; 0.385]$} \\
LED Subscale & 157 & 3.05 & 1.00 & {$[-0.234 ; 0.194]$} & {$[-0.492 ; 0.385]$} \\
\hline
\end{tabular}
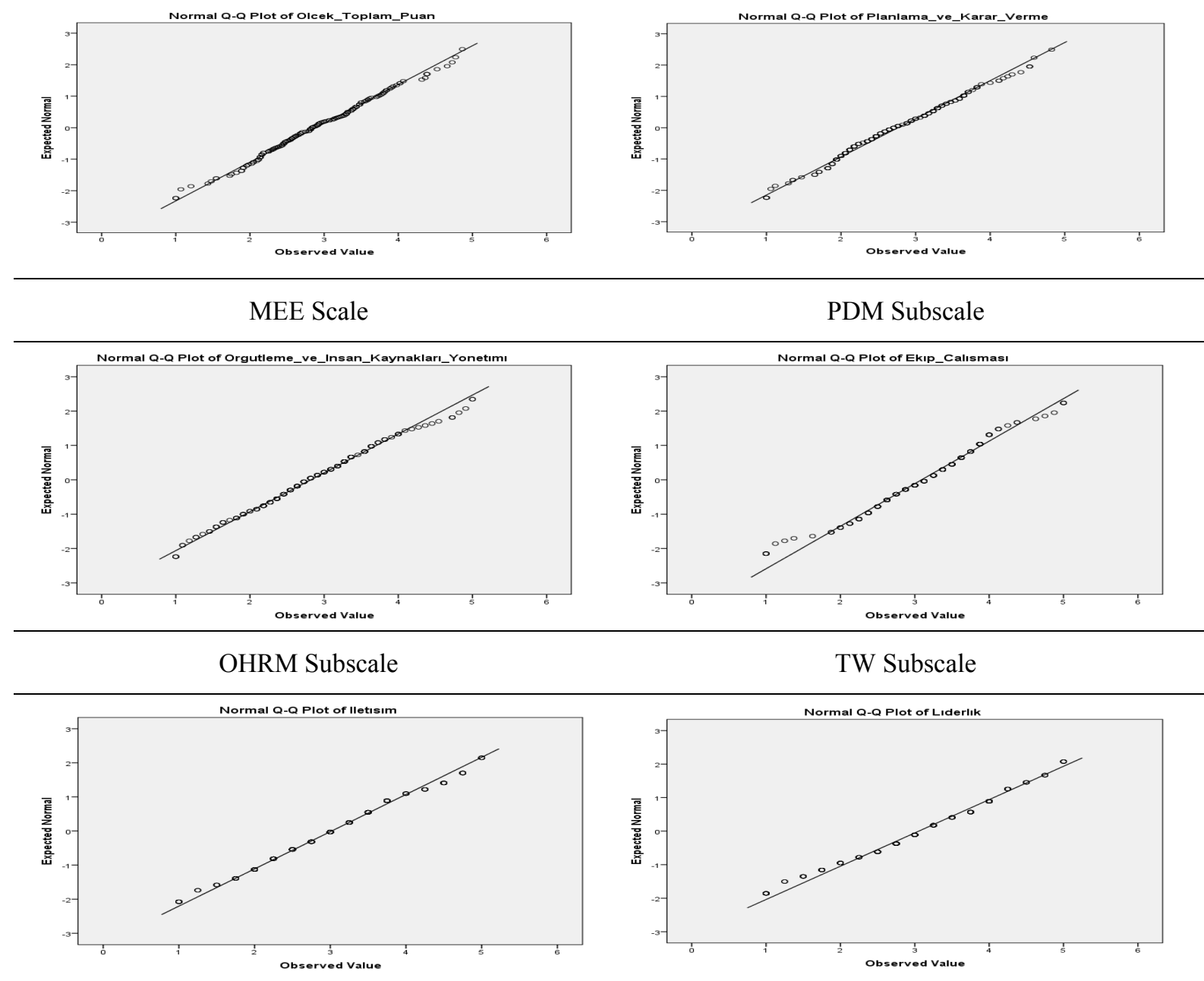

TW Subscale

COM Subscale

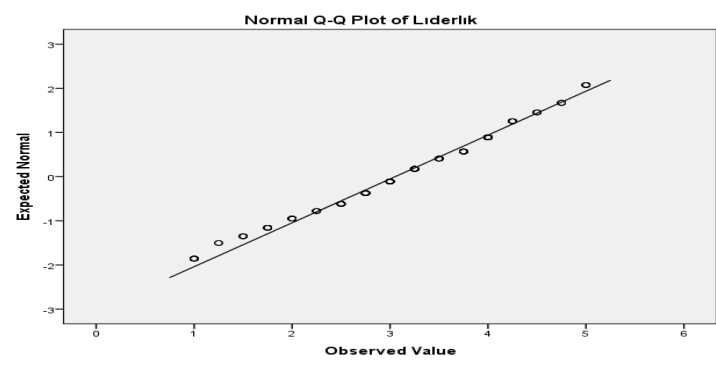

LED Subscale

Figure 1. Q-Q Graphs of MEE Scale and Its Subscales 
Then, frequency and percentage calculations were conducted in order to determine the distribution of the study group according to personal information. The "Independent samples t-test", one of the parametric tests, was conducted in order to evaluate the level of differentiation according to the gender variable, which is an independent variable and the "ANOVA (F test)" test, which is another parametric test, was conducted in order to determine the differentiation according to the period of academic service. For the academic title variable, because the quantitative values of Professors ( $\mathrm{N}=21)$ and Research Assistants $(\mathrm{N}=22)$ were both below 30, "Kruskal Wallis Test", which is one of the non-parametric tests, was conducted. The statistical significance level (alpha $(\alpha)$ error rate) was determined as $\mathrm{p}<0.05$.

The "Pearson Correlation Analysis" was conducted in order to determine the level and direction of the relationships between dependent variables. "Multiple Regression" analysis was conducted in order to better explain the quality of the determined relationship and determine the prediction between MEE scale and its subscales. The statistical significance level (alpha $(\alpha)$ error rate) was determined as $p<0.01$. The correlation relationships between the dependent variables were evaluated according to Table 2 (Kalayc1, 2006).

Table 2. Values Regarding the Relationship between the Dependent Variables

\begin{tabular}{cc}
\hline $\mathrm{r}$ & Correlation \\
\hline $0.00-0.25$ & Very Low \\
$0.26-0.49$ & Low \\
$0.50-0.69$ & Moderate \\
$0.70-0.89$ & High \\
$0.90-1.00$ & Very High \\
\hline
\end{tabular}

\section{Findings}

In line with the aims of the study, the findings obtained from the opinions of the academicians, who serve in Faculties of Sports Sciences in higher education institutions in Turkey, regarding the managerial effectiveness of managers were presented below.

Table 3. Results of the Independent Samples t-test Conducted to Determine Whether the Study Groups Had any Differences According to the Gender Variable

\begin{tabular}{llccccccc}
\hline $\begin{array}{c}\text { The Scale and Its } \\
\text { Subscales }\end{array}$ & Groups & $N$ & $\overline{\mathrm{x}}$ & $S S$ & $\mathrm{Sh}_{\overline{\mathrm{x}}}$ & \multicolumn{3}{c}{$t$ Test } \\
\cline { 6 - 9 } PDM Subscale & Male & 123 & 2.72 & 0.83 & 0.07 & -1.173 & 155 & 0.243 \\
& Female & 34 & 2.91 & 0.78 & 0.13 & & & \\
OHRM Subscale & Male & 123 & 2.76 & 0.89 & 0.08 & -1.382 & 155 & 0.243 \\
& Female & 34 & 3.00 & 0.82 & 0.14 & & & \\
TW Subscale & Male & 123 & 3.06 & 0.79 & 0.07 & -0.698 & 155 & 0.486 \\
& Female & 34 & 3.17 & 0.84 & 0.14 & & & \\
COM Subscale & Male & 123 & 2.98 & 0.89 & 0.08 & -0.931 & 155 & 0.353 \\
& Female & 34 & 3.14 & 0.99 & 0.16 & & & \\
LED Subscale & Male & 123 & 2.96 & 1.00 & 0.09 & -2.034 & 155 & $\mathbf{0 . 0 4 4 *}$ \\
& Female & 34 & 3.36 & 0.96 & 0.16 & & & \\
MEE Scale & Male & 123 & 2.84 & 0.81 & 0.07 & -1.285 & 155 & 0.201 \\
& Female & 34 & 3.04 & 0.80 & 0.13 & & & \\
\hline
\end{tabular}

* $\mathrm{p}<0.05$ significance 
As it can be observed in Table 3, as a result of the t-test conducted to determine whether the MEE scale and its subscale differentiated significantly according to the gender variable, statistically significant differences were determined in the LED subscale $(t=-2.034 ; \mathrm{p}=0.044 ; \mathrm{p}<0.05)$. For MEE scale and other subscales of the scale (PDM, OHRM, TW and COM), no statistically significant difference was observed.

Table 4. Results of the One-Way Variance Analysis (ANOVA) Conducted to Determine Whether the Study Group Had Any Differences According to the Period of Academic Service Variable

\begin{tabular}{|c|c|c|c|c|c|c|c|c|c|c|}
\hline &,$\overline{\mathrm{x}} \mathrm{a}$ & $S S$ & lues & & \multicolumn{6}{|c|}{ ANOVA Results } \\
\hline $\begin{array}{c}\text { The Scale } \\
\text { and Its } \\
\text { Subscales }\end{array}$ & Group & $N$ & $\overline{\mathrm{X}}$ & $S S$ & $\begin{array}{l}\text { Source of } \\
\text { Variance }\end{array}$ & $K T$ & $S d$ & $K O$ & $F$ & $p$ \\
\hline \multirow{4}{*}{ 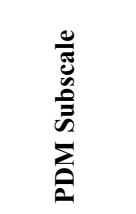 } & $\mathbf{a}$ & 41 & 2.66 & 0.78 & Between & 0.631 & 2 & 0.316 & \multirow{4}{*}{0.465} & \multirow{4}{*}{0.629} \\
\hline & b & 76 & 2.77 & 0.80 & Within & 104.621 & 154 & 0.679 & & \\
\hline & c & 40 & 2.83 & 0.89 & Total & 105.253 & 156 & & & \\
\hline & Total & 157 & 2.76 & 0.82 & & & & & & \\
\hline \multirow{4}{*}{ 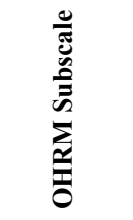 } & a & 41 & 2.77 & 0.77 & Between & 0.463 & 2 & 0.232 & \multirow{4}{*}{0.294} & \multirow{4}{*}{0.746} \\
\hline & b & 76 & 2.79 & 0.86 & Within & 121.321 & 154 & 0.788 & & \\
\hline & c & 40 & 2.91 & 1.02 & Total & 121.784 & 156 & & & \\
\hline & Total & 157 & 2.82 & 0.88 & & & & & & \\
\hline \multirow{4}{*}{ 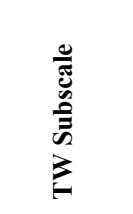 } & $\mathbf{a}$ & 41 & 3.11 & 0.79 & Between & 0.345 & 2 & 0.172 & \multirow{4}{*}{0.262} & \multirow{4}{*}{0.770} \\
\hline & b & 76 & 3.04 & 0.88 & Within & 101.456 & 154 & 0.659 & & \\
\hline & c & 40 & 3.15 & 0.67 & Total & 101.800 & 156 & & & \\
\hline & Total & 157 & 3.09 & 0.80 & & & & & & \\
\hline \multirow{4}{*}{ 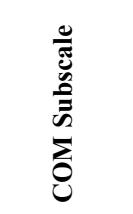 } & $\mathbf{a}$ & 41 & 2.91 & 0.88 & Between & 0.615 & 2 & 0.307 & \multirow{4}{*}{0.363} & \multirow{4}{*}{0.696} \\
\hline & b & 76 & 3.04 & 0.95 & Within & 130.275 & 154 & 0.846 & & \\
\hline & c & 40 & 3.07 & 0.88 & Total & 130.889 & 156 & & & \\
\hline & Total & 157 & 3.01 & 0.91 & & & & & & \\
\hline \multirow{4}{*}{ 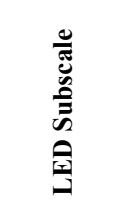 } & $\mathbf{a}$ & 41 & 3.06 & 1.06 & Between & 0.820 & 2 & 0.410 & \multirow{4}{*}{0.402} & \multirow{4}{*}{0.670} \\
\hline & b & 76 & 2.98 & 1.00 & Within & 157.309 & 154 & 1.021 & & \\
\hline & c & 40 & 3.16 & 0.96 & Total & 158.129 & 156 & & & \\
\hline & Total & 157 & 3.05 & 1.00 & & & & & & \\
\hline \multirow{4}{*}{ 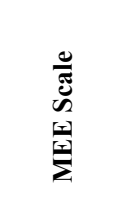 } & $\mathbf{a}$ & 41 & 2.83 & 0.74 & Between & 0.372 & 2 & 0.186 & \multirow{4}{*}{0.280} & \multirow{4}{*}{0.756} \\
\hline & b & 76 & 2.87 & 0.82 & Within & 102.425 & 154 & 0.665 & & \\
\hline & c & 40 & 2.96 & 0.85 & Total & 102.797 & 156 & & & \\
\hline & Total & 157 & 2.88 & 0.81 & & & & & & \\
\hline
\end{tabular}

$a=0-10$ years, $b=11-20$ years, $c=21$ years and above; $p<0.05$ significance

As it can be observed in Table 4, ANOVA analysis was conducted in order to determine whether the MEE scale and its subscales had any significant difference according to the period of academic service. As a result of the analysis, no significant difference was observed in MEE scale and its subscales (PDM, OHRM, TW, COM and LED subscales; $\mathrm{p}>0.05)$. 
Table 5. Results of Kruskal Wallis-H Test Conducted to Determine Whether the Study Group Had Any Difference According to the Academic Title Variable

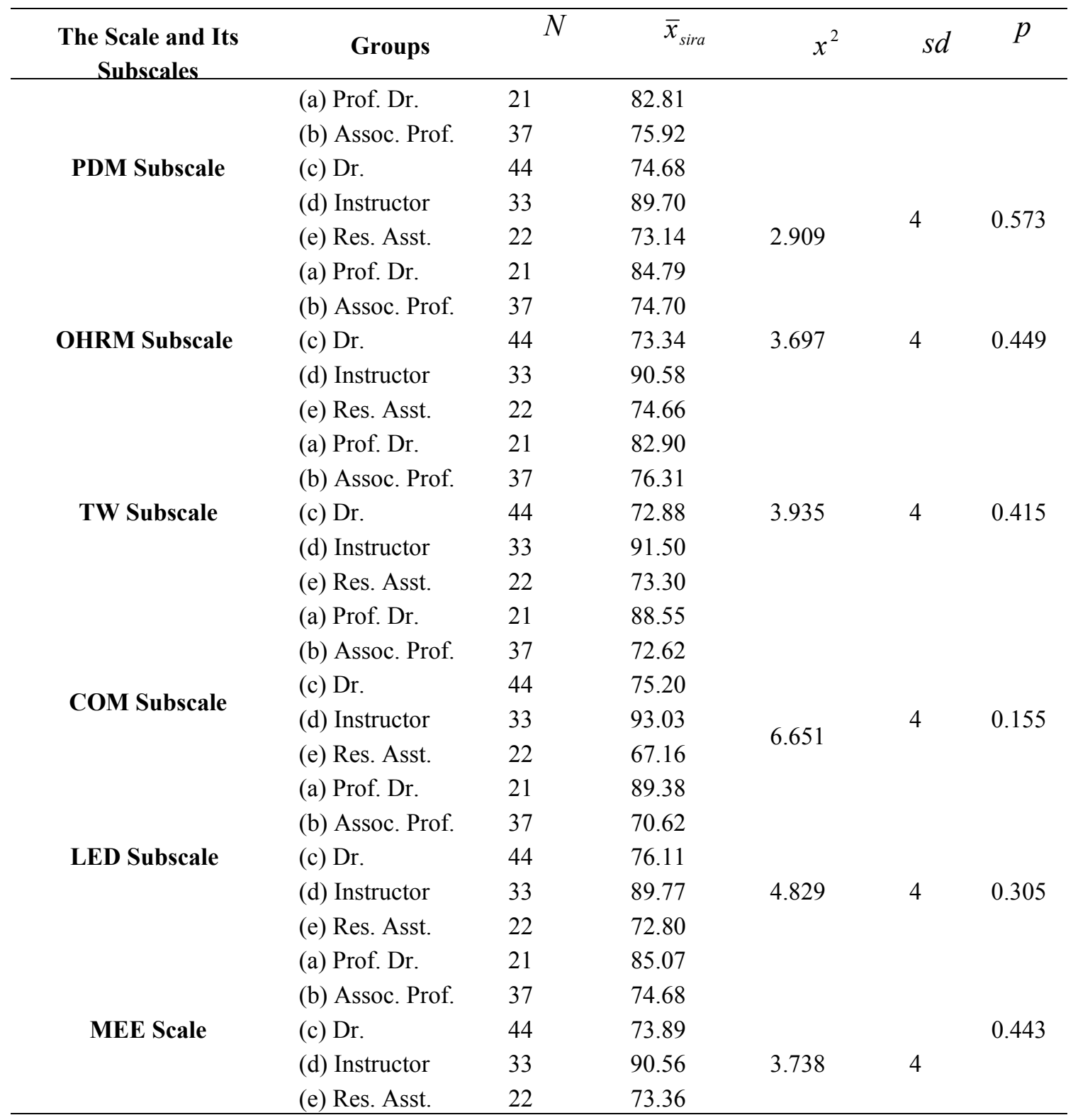

Kruskal Wallis-H analysis was conducted in order to determine whether the study group had any significant differences in MEE scale and its subscales according to the academic title variable (Table 5). It was observed that no significant differences existed in MEE scale and its subscales (PDM, OHRM, TW, COM and LED subscales; $\mathrm{p}>0.05)$.

As it can be observed in Table 6, a significant relationship at a positive way and at a high level was determined between MEE scale and PDM subscale $(r=0.980 ; p<0.001)$ and OHRM subscale $(r=0.978 ; p<0.001)$. The lowest relationship was determined between TW and LED subscales ( $\mathrm{r}=0.694 ; \mathrm{p}<0.001)$, which was at a moderate level. The fact that the correlation ( $\mathrm{r}$ ) values between all the scales were high, raised the problem of linearity. In the study conducted by Vupa \& Alma (2008), it was suggested that the problem of multicollinearity should be investigated in circumstances where the calculated correlation coefficient is " $r>0.75$ ". To conduct a multiple regression analysis, the distribution should be normal, the relationship between dependent and independent variables should be linear and the variables to be used should be continuous (data regarding the normality distribution was presented in the method section (Table1; Figure 1). 
Table 6. Results of the Correlation Analysis Conducted Regarding the Relationship between MEE Scale and Its Subscale

\begin{tabular}{cccc}
\hline Correlation & N & Pearson (r) & $\mathbf{p}$ \\
\hline MEE / PDM & 157 & $\mathbf{0 . 9 8 0}^{* *}$ & $\mathbf{0 . 0 0 0}$ \\
MEE / OHRM & 157 & $0.978^{* *}$ & 0.000 \\
MEE / TW & 157 & $0.878^{* *}$ & 0.000 \\
MEE / COM & 157 & $0.905^{* *}$ & 0.000 \\
MEE / LED & 157 & $0.879^{* *}$ & 0.000 \\
PDM / OHRM & 157 & $0.956^{* *}$ & 0.000 \\
PDM / TW & 157 & $0.810^{* *}$ & 0.000 \\
PDM / COM & 157 & $0.859^{* *}$ & 0.000 \\
PDM / LED & 157 & $0.834^{* *}$ & 0.000 \\
OHRM / TW & 157 & $0.814^{* *}$ & 0.000 \\
OHRM / COM & 157 & $0.860^{* *}$ & 0.000 \\
OHRM / LED & 157 & $0.854^{* *}$ & 0.000 \\
TW / COM & 157 & $0.787^{* *}$ & 0.000 \\
TW / LED & 157 & $\mathbf{0 . 6 9 4}^{* *}$ & $\mathbf{0 . 0 0 0}$ \\
COM / LED & 157 & $0.804^{* *}$ & 0.000 \\
\hline
\end{tabular}

** $\mathrm{p}<0.001$ significance

Furthermore, another presupposition of linear regression analysis is that a linear relationship should exist between the dependent and independent variable. The scatter plot graph regarding this circumstance was presented in Figure 2. In the evaluation of the distribution graph regarding MEE scale, a linear and positive relationship was observed. That indicated that the regression model also provided the linearity assumption.

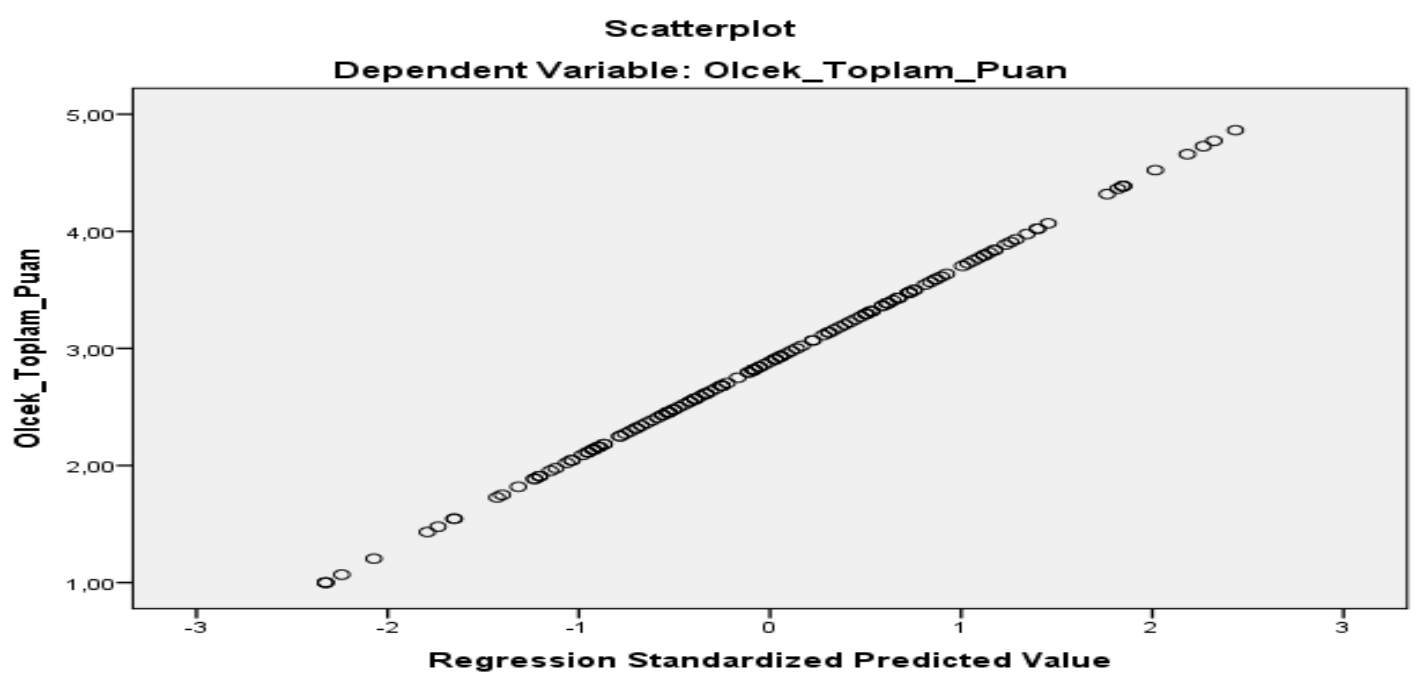

Figure 2. Scatter Plot Graph

In the regression analysis, disturbance terms are regarded as independent from each other. Thus, the test of this assumption was conducted with Durbin-Watson value. With this test, the disturbance terms were tested to investigate whether they affected each other (namely, whether there was an auto-correlation). Durbin-Watson value differs between 0-4. In this study, the Durbin-Watson value was investigated and the result (only for Model 1) was presented in Table 7. Additionally, with the t-tests conducted in the regression analysis, the variables were tested for significance. With the F test (ANOVA), the significance of the whole model was tested. The last construct to be investigated here is to determine the strongest subscale that affects the MEE scale. Thus, it was aimed to conduct analyses to determine each subscales' step-by-step contribution. For this purpose, "stepwise method" was used in the 
regression analysis. In the stepwise method, after determining the independent variables that affect the dependent variable, the independent variables that affect the dependent variable the most were chosen. Starting from the strongest independent variable meeting the mentioned conditions, independent variables that have significant effects on the dependent variable were included in the model one by one.

Table 7. Model Structures Regarding the Effect of MEE Subscales on the MEE Scale

\begin{tabular}{|c|c|c|c|c|c|c|c|}
\hline & $\begin{array}{l}\text { Independent } \\
\text { Variable }\end{array}$ & B & $\mathbf{t}$ & $\mathbf{p}$ & $\mathbf{F}$ & Model (p) & $\mathbf{R}^{2}$ \\
\hline \multirow{3}{*}{ Model 1* } & Constant & - & 4.598 & 0.000 & \multirow{3}{*}{3717.401} & \multirow{3}{*}{0.000} & \multirow{3}{*}{0.960} \\
\hline & PDM & 0.980 & 60.970 & 0.000 & & & \\
\hline & Constant & - & -0.241 & 0.810 & & & \\
\hline \multirow[t]{3}{*}{ Model 2} & PDM & 0.781 & 40.866 & 0.000 & \multirow[t]{3}{*}{3910.460} & \multirow[t]{3}{*}{0.000} & \multirow[t]{3}{*}{0.981} \\
\hline & TW & 0.246 & 12.853 & 0.000 & & & \\
\hline & Constant & - & 1.701 & 0.091 & & & \\
\hline \multirow{5}{*}{ Model 3} & PDM & 0.449 & 18.744 & 0.000 & \multirow[t]{5}{*}{6952.662} & \multirow[t]{5}{*}{0.000} & \multirow[t]{5}{*}{0.993} \\
\hline & TW & 0.202 & 16.677 & 0.000 & & & \\
\hline & OHRM & 0.384 & 15.898 & 0.000 & & & \\
\hline & Constant & - & 0.661 & 0.510 & & & \\
\hline & PDM & 0.421 & 31.372 & 0.000 & & & \\
\hline \multirow[t]{3}{*}{ Model 4} & TW & 0.205 & 30.424 & 0.000 & \multirow[t]{3}{*}{16940.544} & \multirow[t]{3}{*}{0.000} & \multirow[t]{3}{*}{0.998} \\
\hline & OHRM & 0.291 & 20.309 & 0.000 & & & \\
\hline & LED & 0.137 & 18.508 & 0.000 & & & \\
\hline
\end{tabular}

* $\mathrm{R}=0.980 ;$ Durbin-Watson $=1.995 ; \mathrm{p}<0.000$ significance

As it can be observed in Table 7, with the stepwise regression method, 6 independent variables were included in the model one by one and 4 different models were created. In Model 1, the F value is 3717.401 and the significance level is 0.000 while in Model 2, the F value is 3910.460 and the significance level is 0.000 . For Model 3, the F value is 6952.662 and significance level is 0.000 while in Model 4, the F value is 16940.544 and significance level is 0.000 . Accordingly, it was interpreted that there was a significant difference between the means of the variables and the model was significant at every level as a whole. With the $\mathrm{F}$ test, the whole model was tested to determine whether there was a significant difference while with the t-test, the variables were tested to determine whether there was a significant difference (5\% significance level). It was determined that every subscale had a significance within the model. As it can also be observed in Model 1, PDM subscale predicts the $96 \%$ of the variance of MEE scale $\left(\mathrm{R}^{2}=0.960\right)$. According to the $\mathrm{t}$-test, it was observed that with the constant value, PDM subscale was significant $(\mathrm{p}<0.001)$. In the examination of the model created between PDM subscale and MEE Scale as a whole, the model was determined to be significant $(\mathrm{F}=3717.401 ; \mathrm{p}<0.001)$. In the evaluation of the Durbin-Watson coefficient, the fact that the value is 1.995 could be interpreted as a fine value, namely, the PDM subscale affects MEE scale $(\beta=0.980)$. In Model 2, PDM subscale and TW subscale were included in the analysis and the prediction power of these two subscales reached $98 \%\left(R^{2}=0.981\right)$. In Model 3, it was observed that the prediction power of PDM, TW and OHRM subscales regarding MEE scale reached $99 \%\left(\mathrm{R}^{2}=0.993\right)$. In Model 4, it was observed that the prediction power of PDM, TW, OHRM and LED subscales regarding MEE scale reached $100 \%\left(\mathrm{R}^{2}=0.998\right)$. Finally, it was determined that the subscale with the strongest prediction power for MEE scale was PDM subscale (Model 1).

\section{Discussion and Conclusion}

The findings obtained within the framework of the analyses conducted in this study were interpreted as the following:

In the LED subscale from the subscales of MEE scale, a significant difference was determined in the gender variable. No significant difference was observed in the other subscales (PDM, OHRM, TW and COM subscales). While in the LED subscale, the general opinions of the female academicians were partially agreeing, the opinions of male academicians were generally disagreeing. This difference was thought to be related to the study group's perceptions 
of autonomy, hierarchy and centralization concepts. The examination of other studies revealed similar results: Balay, Kaya, Melik, (2014) reported in their study that the managerial effectiveness perceptions of the study group did not create a significant difference according to gender. However, it was determined that the managerial effectiveness perceptions of females were higher compared to those of males. Furthermore, the managerial effectiveness perceptions of the study group towards their organizations were determined to be generally moderate. In the study conducted by İra (2011) regarding the subject, it was determined that there was no significant difference in the perceptions of academicians according to gender in the managerial effective scale and its subscales. In the study conducted by Şahin (2013: 62), it was determined that there was no significant difference in the managerial effectiveness scale and its subscales according to gender. This state indicates that females and males have similar opinions regarding the managerial effectiveness levels of managers. In contrast, in the study conducted by Koçak \& Helvac1 (2011), significant differences were determined in the opinions of academicians according to gender.

In the evaluation of the opinion of the study group in MEE scale and its subscales, no statistically significant difference was detected according to the period of academic service. Academicians who had 21 years or above experiences expressed more positive opinions regarding the managerial effectiveness of their managers compared to the other academicians. However, these opinions did not create a statistically significant difference. Similar results were also reported in other studies: Koçak \& Helvacı (2011) reported in their study that the opinions of the study group did not create a statistically significant difference according to the seniority variable. In contrast, in the study conducted by Şahin (2013), it was reported that those with 26-30 years of seniority expressed moderate levels of managerial effectiveness for the managers compared to others. Additionally, those with 26-30 years of seniority believed that managers had lower levels of technical abilities compared to others. In the study conducted by İra (2011), it was reported that academicians had significant differences in the "planning and decision-making", "organizing and human resources" and "leadership" subscales according to seniority. Nurluöz, Birol, \& Silman, (2010) conducted a study investigating the behaviors of managers in education in Universities in Turkey and TRNC (Turkish Republic of Northern Cyprus). They reported that there were significant differences in the opinions of academicians according to their period of service. Academicians with long years of service expressed more positively oriented opinions.

It was observed that the opinions of academicians with the titles of Prof. Dr and Instructors had more positive opinions compared to those with other titles. However, this result did not create a statistically significant difference in MEE scale and its subscales. Similar results were reported in other studies. Nurluöz, Birol, \& Silman, (2010) reported in their study that there was no statistically significant difference in academicians' perceptions of their managers' behaviors according to academic titles. Furthermore, in the study conducted by İra (2011), it was reported that there was no statistically significant difference in the subscales of "planning and decision-making", "organizing and human resources", "teamwork", "communication" and "leadership" according to the titles of the academicians.

The following results were observed in the evaluation of the MEE scale and its subscales in the study: there was a statistically significant difference in the LED subscale according to the gender variable. In the MEE scale and its subscales, there was no statistically significant difference according to the independent variables (gender, the period of academic service and academic title). In other studies conducted, the following results were reported: in the study conducted by İra (2011), it was reported that the highest points were received in the "leadership" subscale regarding the academicians" opinions of managerial effectiveness. Then, the subscales of "communication", "teamwork" and "organizing and human resources" follow, respectively. It was also reported that the lowest level was that of "planning and decision-making" subscale. In another study, it was reported that the opinions of the study group regarding managerial effectiveness were at a moderate level in the subscales of "planning and decision-making", organizing and human resources management", "teamwork" and "communication" while it was at a sufficient level at "leadership" subscale (Balay, Kaya, \& Melik, 2014). In the study conducted by Karslı (2004), it was reported that there were appropriate levels of managerial effectiveness measurements, which were created by synthesizing the four levels in university organization, "individual", "team", "study group" and "policy and strategy" with subscales of organization effectiveness, "adaptation", "achieving the aim", "integration" and "establishing and maintaining a values system".

In the correlation analysis, the strongest relationships were determined between the PDM and OHRM subscales of MEE scale, which were in a positive way and at a very high level. As a result of the regression analysis performed, it was determined that the subscale with the highest prediction power of MEE scale was the PDM subscale. PDM subscale predicts the $96 \%$ of the variance in MEE scale. In the study conducted by Kaya, Balay, \& Tinaz, (2014), it was reported that there was a relationship between the managerial effectiveness and organizational commitment 
perceptions of managers and teachers, which was in a positive way and at a high level. As a result of the regression analysis conducted, it was reported that the managerial effectiveness perceptions of managers and teachers predicted their opinions of organizational commitment in a positive way and at a high level, which was determined to be significant. According to this result, it was reported hat that managerial effectiveness was a predictor of organizational commitment. Regarding this subject, Balay (2014: 461) reported that there was a relationship in a positive way and at a high level between the organizational creativity and managerial effectiveness perceptions of teachers.

In the review of various studies about managerial effectiveness, it was observed that different conclusions were reached. For example, Burgaz \& Şentürk (2008) reported in their study that academicians wished that there was a democratic and participatory concept of management in faculties of education. For this purpose, it was reported that all of the academicians in the faculties of education, regardless of their positions and titles, should express their opinion in all of the scales of managerial effectiveness and participate. In the study conducted by Günal (2006), it was concluded that the academicians from the education faculty among other faculties were aware of the problems in achieving organization goals and they moderately agreed with the problems experienced in the opportunity of education-research. The most important problem perceived by the academicians were the quality of academicians the problem of democratizing. In the study conducted by Bakan, Büyükbeşe, \& Bedestenci (2004), it was reported that academicians had the opinion that the board level management had too much of an influence on the way that academic units function. In the study conducted by Alamur (2005), it was reported that in Anadolu University, the academicians had a high level of cooperation and coordination with the board level management and the board level management supported their managerial effectiveness.

As a result of the study, the managerial effectiveness of managers was determined to be at a moderate level according to the opinions of the academicians. Considering this result, it could be suggested that the Faculties of Sports Sciences are not managed in a rather effective way. This state prevents faculties of sports sciences from achieving their managerial effectiveness and aims at the desired level. Especially the field of sports sciences should be examined and investigated in a continuous evaluation process. This is because faculties of sports sciences should be constantly developed in order to raise the sports scientists (students who are candidates of physical education teachers, sports managers, coaches and recreation managers) with the quantity and the quality that today and future demands. Thus, managers of the institutions should emphasize the organizational works by believing in the shared wisdom. In these institutions, cooperative and interactive management models should be implemented as the organizational structure and the management concept. In providing organization effectiveness, faster progress could be achieved by including participation, leadership and volunteerism of academicians and managers in the process. Additionally, activities such as in-service training and seminars should be held in order to improve the awareness, knowledge and expectancy levels of academicians regarding globalization and the effects of globalization. Finally, it is believed that improving the managerial effectiveness of faculties of sports sciences will provide them with better management, enabling them to achieve their scientific and academic goals. It is of utmost importance that faculties of sports sciences, which are regarded as one of the leading forces in social upheaval, should have managers with leadership qualities who can direct the human resources of each department in an efficient and correct way. The studies regarding managerial effectiveness in these institutions could also be improved by including the students. In short, managerial effectiveness is necessary for faculties of sports sciences for management and leadership behaviors. This is because the existence of multifaceted and dynamic faculties of sports sciences and the continuum of this existence is only possible with the abilities that lie behind the components of the managerial effectiveness concept. Finally, considering the roles of educational institutions in shaping the world, managerial effectiveness along with all the components that constitute the managerial field of educational institutions could be subjected to similar investigations in future studies in order to contribute to the ideal that effectively managed education institutions provide effective education.

\section{References}

Alamur, B. (2005). A Research for the relationship between organizational culture and commitment and the application at the Anadolu university faculty of economic and administrative sciences, Anadolu University, Master Thesis, Eskişehir. https://doi.org/10.17261/Pressacademia.2017.475

Aydın, M. (1994). Ĕ̈itim yönetimi: kavramlar, kuramlar, süreçler, iliş̧kiler (trans.: Education Management: concepts, theories, processes, relationships), Hatiboğlu Publishing, Ankara.

Bakan, İ., Büyükbeşe, T., \& Bedestenci, H. Ç. (2004). Örgüt kültürü̈: teorik ve ampirik yaklaşım (trans.: 
Organizational Culture: theoretical and empirical approach), Aktüel Publishing, Bursa.

Balay, R., Kaya, A., \& Melik, G. (2014). The relationship between perceptions of middle school teachers' organizational creativity and managerial effectiveness, Kastamonu University, Kastamonu Education Journal, 23(2), 460- 461.

Başaran, İ. E. (1982). Örgütsel davranışın yönetimi (trans.: Management of organizational behavior), Ankara University, Faculty of Educational Sciences Publications, Ankara.

Burgaz, B., \& Şentürk, İ. (2008). The effects of globalization on the administrative dimension of education faculties. Manas Journal of Social Sciences, 19.

Cook, M. D. (2008). Exploring the impact of management functions on indigenous policy, Doctoral Dissertation, North Central University.

Cyril, P. (1999). Restructuring the key to effective school management. USA, Canada: Routledge.

Demir, E., Saatçioğlu, Ö., \& İmrol, F. (2016). Examination of educational researches published in international journals in terms of normality assumptions, Current Research in Education, 2(3), 130-148. https://doi.org/10.5281/zenodo.1307186.

Dilber, M. (1976). Yönetsel ve örgütsel etkililiğe davranışsal yaklaşım (trans.: Behavioral approach to managerial and organizational effectiveness), Boğaziçi University Publications, İstanbul.

Doğan, S., \& Şahin, F. (2011). Yönetsel güçlülük ve etkililik: kavramsal bir çalışma (trans.: Managerial strength and effectiveness: a conceptual study), Atatürk University. Journal of Economics and Administrative Sciences, $25(2), 61-62$.

Farahbakhsh, S. (2007). Managerial effectiveness in educational administration: concepts and perspectives. Management in Education, 21, 33. https://doi.org/10.1177/0892020607076659

Günal, S. Ö. (2006). Management problems of higher education, Dokuz Eylül University, Institute of Educational Sciences, Doctoral Dissertation, İzmir, Turkey.

Horngren, T. C., Foster, G., \& Datar, M. S. (2000). Cost accounting a managerial emphasis (10 ${ }^{\text {th }}$ Ed.). London: Prentice Hall International.

Hoy, W. K., \& Miskel, G. C. (1996). Educational administration: theory, research and practice (3rd Ed.). New York: Random House, Inc.

İra, N. (2011). Organizational culture and managerial effectiveness in faculties of education, Dokuz Eylül University, Institute of Educational Sciences, Ph.D. Thesis, İzmir, 54-64.

İra, N., \& Şahin, S. (2010). Adaption of managerial effectiveness scale to Turkish. Buca Education Faculty Journal, $28,16-29$.

Kalayc1, Ş. (2006). SPSS uygulamalı çok değişkenli istatistik teknikleri (trans.: SPSS applied multivariate statistical techniques), Asil Publication Distribution, Ankara.

Karakaya, Y. E. (2013). Organisational commitment levels of faculty members in sport education institutions in Turkey. South African Journal for Research in Sport, Physical Education and Recreation, 35(2), 141-152.

Karasar, N. (2009). Bilimsel araştırma yöntemi: kavramlar, ilkeler, teknikler (trans.: Scientific research method: concepts, principles, techniques), 7. Printing, 3A Research Education, Danışmanlık Ltd. Com., Ankara.

Karatepe, S. (2005). Managerial effectiveness: in school administration dimension of the managerial effectiveness of relationships with subordinates. Süleyman Demirel University, Journal of Economics and Administrative Sciences, 10(2), 307-326.

Karsl, D. (2004). Yönetsel etkililik (trans.: Managerial effectiveness), Pegem Publishing, Ankara.

Kaya, A., Balay, R., \& Tinaz, S. (2014). The relationship between managerial effectiveness and organizational commitment perceptions of teachers and principals. Ahi Evran University, Journal of Kırşehir Education Faculty, 15(2), 95 .

Koçak, F., \& Helvacı, M. A. (2011). The effectiveness of schools principals (Uşak case). Journal of Educational Sciences Research, 1(1), 33-55.

MacBeath, J. (1998). Effective school leadership: responding to change. Paul Chapman Publishing Ltd., London. 
Murat, G., \& Açıkgöz B. (2007). An analysis of the managers' perceptions about organizational culture: the case of zonguldak karaelmas university, Zonguldak Karaelmas University. Journal of Social Sciences, 3(5), 2-20.

Murry, J. (1993). Development of assessment criteria to determine the managerial effectiveness of community and technical college administrators, Doctoral Dissertation, University of Arkansas.

Nurluöz, Ö., Birol, C., \& Silman, F. (2010). Examining administrative behaviors of educational administrators in universities by perceptions of academic staff and students. Educational Administration: Theory and Practice, 16(4), 579-599.

Popli, S. (2005). Ensuring customer delight: a quality approach to excellence in management education. Quality in Higher Education, 11(1), 17-18. https://doi.org/10.1080/13538320500078874

Şahin, A.E. (2001). Delphi technique and its uses in educational research, Hacettepe University. Journal of Education Faculties, 20, 215-220.

Şahin, S. (2013). Teachers' opinions about the level of elementary school principals' administrative effectiveness (Izmit case)', Master Thesis, Hacettepe University, Social Sciences Institute, Ankara, 62.

Tabachnick, B. G., \& Fidell, L. S. (2007). Using multivariate statistics. Allyn \& Bacon, Pearson Education.

Vupa, Ö., \& Alma, Ö. G. (2008). Investigation of multicollinearity problem in small samples included outlier value in linear regression analysis, Selçuk University. Journal of Science and Literature, 31, 97-107.

Welsh, F., Petresko, M., \& Metcalf, J. (2003). Institutional effectiveness activities: faculty and administrator support at two-year institutions, Community College Journal of Research and Practice, 27(2), 75-94. https://doi.org/10.1080/713838114

Yılmaz, K., \& Taşdan, M. (2006). A qualitative research on the school administrators' thoughts about effectiveness in school administration, Ankara University. Journal of Educational Sciences, 39(2), 125-150.

Yukl, G. (2008). How leaders influence organizational effectiveness. The Leadership Quarterly, 19, 708-722. https://doi.org/10.1016/i.leaqua.2008.09.008 